\title{
In 111 Folic Acid
}

National Cancer Institute

\section{Source}

National Cancer Institute. In 111 Folic Acid. NCI Thesaurus. Code C2506.

A radioimmunoconjug ate of folic acid labeled with indium 111 (In-111) with

immunotherapeutic property. In 111 Folic Acid emits gamma radiation and X-Ray

photons that can be captured by gamma camera allowing imaging of tumor cells that express folate receptors. 